\title{
THE ROLE OF CULTURAL HERITAGE IN THE CREATION OF A SENSE OF BELONGING AMONG YOUNG NORWEGIAN TURKS: BOUNDARY MAKING AND CROSSING
}

\author{
KAROLINA NIKIELSKA-SEKULA ${ }^{1}$
}

\begin{abstract}
This paper discusses the importance that cultural heritage has for Norwegians of Turkish decent when it comes to negotiating both their belonging and the concept of home. The role of heritage in making and crossing the boundaries of ethnicity is also discussed here. I argue that Norwegian Turks have developed a multi-layered sense of belonging based on the identification with groups and places located both in Turkey and in Norway. They participate in Norwegian society while identifying themselves as Turks and negotiations of cultural heritage contribute to the preservation of consistent image of themselves as they adopt common Norwegian lifestyles.
\end{abstract}

Keywords: Belonging, Cultural Heritage, Turkey, Norway, Alevi, Sunni.

Summary: I. INTRODUCTION; II. From TURKEY to NORWAY; III. NORWEGIAN TURKS IN DRAMMEN; IV. Ethodology; V. Heritage and Belonging. Boundary Making and Crossing; V.1. Dual Belonging; V.2. Dual (non)belonging; V.3. Heritage: boundary making and crossing; VI. ConCLUSIONS.

\section{INTRODUCTION}

In his book "The Perils of Belonging: Autochthony, Citizenship, and Exclusion in Africa and Europe”, Peter Geschiere (2009)points out that in Europe we are currently witnessing a shift towards an autochthonic interpretation of belonging according to which the rightful inhabitants of the territory are those who have been bounded to the land across generations. Consequently, immigrants have a limited access to membership of autochthonous communities of Europe, despite the existence of available opportunities of obtaining European citizenships. The othering processes are extended to immigrants ` children who have been born and raised in the new homelands, but are still stigmatised as "foreign". Taking into account the complex position of people that come from a minority group in Europe, this paper analyses how Norwegians of Turkish descent negotiate their belonging and concept of home with help of cultural heritage. It aims to provide an answer to the question of whether heritage contributes to the cultural integration of immigrants or limits it instead. The use of heritage in making and crossing the boundary of ethnicity is also discussed here. The paper seeks to contribute

\footnotetext{
1 MiReKoc, Koc University, Istanbul and IKH, University College of Southeast Norway, Bø (karolinanikielska@gmail.com). I would like to thank my supervisor and anonymous reviewers for their valuable comments on the earlier draft of this paper.
} 
to the debate surrounding the sense of belonging of minorities by contributing to the knowledge of the role of cultural heritage in the construction of the sense of belonging.

Studies on belonging have received much attention from scholars, especially during the2000s (for an overview see Lähdesmäki et al., 2016). The issue was widely discussed in relation to immigrants, whose allochthonous (Geschiere, 2009) position in new homeland societies raised questions about the processes of identity negotiations and the so-called in-betweenness. Lähdesmäki et. al. sum recent trends in research on belonging as follows:

The timely topoi [in research on belonging] are closely related to the contemporary phenomena of migration, transnationality, interculturality, and globalization. Rethinking belonging in the context of increased levels of mobility has led researchers to discuss various forms of multiple belonging, such as multicultural, diasporic, and trans-local belonging, and to investigate problematic issues such as discrimination, inequality, and tensions between individuals and communities that the negotiation on belonging may include (Lähdesmäki et al., 2016, p. 241).

Belonging is understood in this paper as a lifelong process that has more in common with the concept of identification with groups and places than with an essentialist and rather stable notion of identity. ${ }^{2}$ Flora Anthias (2016, p. 7) conceptualises belonging as "to what' and 'with whom' one is a member, where and by whom one is accepted and feels attached to". Nira Yuval Davis (2006) argues that there is a difference between belonging and the politics of belonging. Belonging refers to the idea of "feeling at home" within a particular socio-geographical setting, while the politics of belonging seek to relate belonging to specific groups via planned political programs (Yuval-Davis 2011, pp.4-5). I argue that the politics of belonging are not exclusively implemented through official policies, but also through identity strategies present within minority communities, including families. This paper focuses primarily on a personal feeling of belonging that comprises feeling at home, yet it also pays attention to strategies used to create a sense of belonging that are present in NorwegianTurkish communities.

The concept of home is an important part of the process of creating a sense of belonging. Sara Ahmed, in the context of spatial mobility, explains the notion of home as twofold. She defends that "[t]he journeys of migration involve a splitting of home as place of origin and home as the sensory world of everyday experience” (Ahmed, 1999, p. 343). The former dimension of home is linked to an idealised concept of homeland, something that is common in diaspora communities. It has been argued that so-called diaspora communities are characterised by a shared idea of an imagined homeland (Gupta \& Ferguson, 1992), an idealised place of autochthonic origin, dating several

\footnotetext{
${ }^{2}$ For the criticism of the notion of identity see, for instance, Anthias (2016)
} 
generations back. Galip describes this tendency as follows:"[b]ecause of a geographical existence away from 'home`, coupled with idealised longing to return there, diasporas are frequently characterised as having an imagined or `mythical home” (Galip, 2015, pp. 120-121). Narrations about an idealised homeland constitute an important element of identification for the members of diaspora. As Gupta and Ferguson put it: "[r]emembered places have often served as symbolic anchors of community for dispersed people. (...) "Homeland" in this way remains one of the most powerful unifying symbols for mobile and displaced people” (Gupta \& Ferguson, 1992, p. 11).

The narration of foreignness of immigrant minorities in Western countries often involves the issue of problematic cultural practises. In the context of international migration, as some scholars have said, culture has become an explanatory factor for the conflicts between immigrants and native members of the receiving societies (Alghasi, Eriksen \& Ghorashi 2009, p.5). This perspective places immigrants and their offspring in a quite unprivileged position: they are foreigners in their new homelands who share practices that are questioned and assumed as limitations to their integration. Such position also applies Norwegian Turks, who, being the so-called non-Western, Muslim minority of Norway, have been targeted by anti-immigrant rhetoric in Norwegian public debate. ${ }^{3}$ However, from the point of view of minorities, culture - understood as a set of values, traditions and patterns of behaviour brought by the first generation of newcomers from their background localities - is often seen as a positive, distinguishing factor. Some of these practices, traditions and values constitute the cultural heritage of a group and an important reference for self-identification of the members of minorities. According to the work of several scholars, cultural heritage is understood here as a representation of the past in the present (Petterson 2009, p.66), which is never objective and always based on the present needs of particular groups and the power relations within them (Graham 2002, p.1004; Macdonald 2013). Heritage is created in the processes of remembering and forgetting (Graham 2002, p.1004) and can be represented via tangible and intangible elements such as values, traditions, practices, artefacts or landscapes. Heritage is collective and is usually linked to the level of a group or institution. Nevertheless, heritage is reproduced and refined by the actions of individuals. This paper focuses on traditions, values and practices of individual members of the Turkish minority in Norway, as these elements constitute heritage and are the arenas in which heritage is negotiated.

The theoretical framework of the paper is supported by Fredrik Barth’s concept of ethnicity and ethnic boundaries (Barth 1969). Ethnicity is regarded here as "a social process of maintaining boundaries that the people themselves recognize as ethnicity" (Baumann 1999, p.59). Thus, it is understood as an organizational principle (Barth 1994) and an effect of social interactions and individuals' self-consciousness (Cohen 1994), not as an expression of natural cultural differences.

\footnotetext{
${ }^{3}$ It have been argued that anti-immigration discourses in Norway concern mainly non-Western immigrants with a special regard to Muslims (Andersson, 2012; Bangstad, 2011; Vestel, 2009).
} 
Research on Turks in Europe has been widely developed since the arrival of first "guest workers" in the 1960s, concentrating primarily on economic issues and the dream of returning. In the 1970s, analyses were centred on different aspects of cultural integration and identity formation, whereas in the 1990s works on citizenship, racism, discrimination and diasporic networks (Kaya, 2007, p. 484) came into the picture. The countries in which most of the research was carried out were those that have a relatively high Turkish population, such as Germany (Çağlar, 2001, 2004; Güney, Kabaş, \& Pekman, 2016; Kaya, 2001, 2002; Pécoud, 2004; Petzen, 2004; Soysal, 2001), the Netherlands (Bolt \& van Kempen, 2002; De Valk \& Liefbroer, 2007; Spierings, van Melik, \& van Aalst, 2016; van Eck, 2002) and Belgium (Adriaens, 2014; Blommaert, Collins, \& Slembrouck, 2005; Phalet \& Swyngedouw, 2002; Reniers, 2001). There are only a few existing works (Rogstad, 2009; Sandrup, 2013; Zirh, 2012) about Turks in Norway and little is known about the negotiations of belonging and on how Norwegian Turks use and participate in heritage. What is more, European research on Turkish migration was mainly conducted in a context of urban metropolis such as Berlin, while the livelihoods of European-Turks inhabiting mid-sized cities are still insufficiently analysed. This paper seeks to address these empirical gaps in Turkish migration studies, focusing on Turks in Norway in the context of the mid-sized city of Drammen. I begin with a brief presentation of migration processes from Turkey to Norway, then I present the characteristics of a heterogeneous community of Turks in Drammen and discuss the methodological assumptions of the study. Finally, I analyse the processes that Norwegian Turks go through to construct their belonging and the concept of home, as well as their use of heritage.

\section{FROM TURKEY TO NORWAY}

In 1923, Mustafa Kemal Ataturk founded the Modern Republic of Turkey in the place of the remains of the Ottoman Empire. Extensive modernization, secularization and westernization of the country contributed to building the current position of Turkey, often seen as a bridge between so-called Western countries and predominantly Muslim Middle Eastern countries. The population of Turkey is estimated to be almost 80 million people and most of them are Muslim, predominantly Sunni Muslim. Historically, the country was home to many religious and ethnic minorities, including a significant number of non-Muslim groups such as Greeks, Armenians and Jews. However, during the nation building process, Islam became the definition of Turks and the otherness of non-Muslim ethnic minorities came to the fore. This in turn led to the voluntary or forced emigration from Turkey of non-Muslim minorities (Içduygu et.al. 2008: 359). Nonetheless, contrary to appearances, in spite of having 99\% Muslim population (ibidem), Turkey nowadays is not a homogeneous land (Shankland 2007: 14). Its biggest current ethnic minority are the Kurds, who represent 15-20\% (Romano 2014) or even, according to some authors (McDowall 2007), 23\% of the total population of Turkey. The biggest religious minority are the Alevis, which representapproximately15\% of the Turkish population (Dressler 2008: 281; Shankland 2007: 20). 
Migration from Turkey to Norway has generally mirrored the general labour mobility pattern from Turkey to Western Europe with the arrival of pioneers who were followed later on by their families. The first Turks went to Norway as "guest workers" at the end of the 1960s. In 1970 there were already 260 Turks in the country, and together with Moroccans, Pakistani and citizens of India, they represented $40 \%$ of the immigrant population coming from developing countries to Norway (Brochmann \& Kjeldstadli 2008, p.194). The area of Drammen was the main destination for newcomers from Turkey. As Næess(1985, p.52) indicates, the first group of Turks came to Mjøndalen Cellulose in 1967 from Șivaslı, located in Ușak (Turkey). After that, many small groups of Turkish workers arrived in Drammen. A significant number of guest workers came from Beyșehir, which is located in the Konya province (Türker 2000, p.34). Given that the main reason behind Turkish migration to Norway was to take unskilled jobs (Blom 1997, p.17; in Nistov 2001, p.94; Steinkellner \& Rustad Holseter 2013, p.34), those who were recruited had a poor level of education, especially women. Today, despite the fact that immigrants come from different regions of Turkey, inhabitants of Turkish origin have their roots first and foremost in the villages surrounding Konya and Ușak, Ankara and the village called Sivas. Most of them live in Oslo and Drammen, but also in Moss, Trondheim, Stavanger and Lørenskog. There are currently 21,424 people of Turkish origin in Norway (SSB Statistics Norway 2015) and migration from Turkey to Norway continues, although at a relatively smaller scale.

The Norwegian immigration policy model is generally classified as "de facto multiculturalism” (Akkerman \& Hagelund 2007, pp.197-198). The country, however, has never declared multiculturalism as its official policy (Hagelund 2003). In 1980, the assimilationist strategy towards immigrants was officially rejected and immigrant culture was given the right to protection (Hagelund 2002, p.407). Providing equal rights and duties towards society, as well as the inclusion of immigrants in Norwegian society has been the main aim of Norwegian immigration policy for a long time (Stjernø Committee 2008, pp.69-70). Recently, the idea that cultural diversity is an important resource in multicultural Norway has been included(Meld. St. 6 2012), transforming, at least at an official level, immigrants' “cultural” characteristics into positive values.

\section{NORWEGIAN TURKS IN DRAMMEN}

Research discussed in this paper was conducted among Norwegian Turks in the city of Drammen between December 2012 and January 2014. It is comprised of 12 indepth interviews, with seven female and five male second and third-generation Norwegian Turks. Interviews were analysed in the context of data collected during an extensive ethnographic observation in Drammen that was conducted simultaneously with the interviews. The observation was comprised of photo documentation of the area, participation in activities organized by and for Norwegian Turks, semi-structured interviews with owners and employees of the facilities run and frequented by Norwegian Turks, expert interviews and unstructured interviews with the inhabitants of the city. 
The majority of the participants' ancestors came to Norway as guest workers from small villages in the Konya province of Turkey. Konya is one of the most conservative areas of Turkey, populated predominantly by Sunni Muslims. One respondent said to have roots in a village in the area of the Black Sea in Turkey, further to the north. Due to internal migration in Turkey, many of respondents' family members who remained in Turkey now live in bigger cities such as Ankara, Istanbul or Izmir. The rest have stayed in their hometowns. All of these places are destinations of yearly trips to Turkey, popular among the majority of the respondents.

All but one respondent was born in Norway. Everyone has studied in the Norwegian educational system and is fluent in Norwegian, and also, at the time of the interview all of them were either employed or enrolled at the university. The jobs of those who worked ranged from manual labour to kindergarten teachers, sales assistants, waiters and qualified office workers. Generally, more women than men had graduated from university. Moreover, none of the women were employed as manual labourers. Respondents were aged between 19 and 35 years. Some of them were single, some were married or married with kids; a heteronormative form of marriage was taken for granted by all of them. Six respondents had an Alevi background, while five of the participants had Sunni roots.

The city of Drammen, which is where the data was collected, is located in the eastern part of Norway and it is not far from Oslo, the Norwegian capital. 25\% of the city's inhabitants are of immigrant origin ${ }^{4}$ (Høydahl 2014) and the majority of these people have a Turkish background (13,5\%). $62 \%$ of the people of Turkish origins who settled in Drammen have been living in Norway for more than 21 years. This means that they are quite well-settled and have made their imprint on the city's landscape by opening ethnic facilities, mostly in Drammen's commercial ethnic neighbourhood, such as halal butcher shops, restaurants and groceries which sell imported products and serve Turkish cuisine. Moreover, Norwegian Turks have changed the meaning of many places in Drammen by establishing Turkish mosques and ethnic clubs inside the existing buildings, churches included, and by giving them a transnational dimension. People of immigrant backgrounds are present in all of the city's districts. However, the biggest concentration $\left(44 \%{ }^{5}\right)$ was observed in the Fjell district, where most of the dwellings are housing blocks.

The Turkish minority in Drammen is highly diversified and does not constitute one homogeneous community of the Turks. There are three different mosques for Sunni Muslims, an Alevi cultural centre and several informal ethnic clubs in the city in which different groups of people gather. The majority of Drammen's Norwegian Turks originate from the Konya province, but some of them also come from different places, and there are even a few ethnic Turks from Bulgaria ${ }^{6}$. Moreover, there is an existent boundary between Sunni Muslims and Alevi Turks, even if both groups originate from

\footnotetext{
${ }^{4}$ Immigrants and Norwegian-born to two immigrant parents (SSB Statistics Norway 2015)

${ }^{5}$ As noted in Drammen Kommune (n.d. available online).

${ }^{6}$ Bulgarian Turks appear in Norwegian statistics as Bulgarians, even though they identify themselves as Turks.
} 
the same area of Konya. All of these characteristics overlap with socio-economic differences between individuals.

The members of the Alevi community in Drammen generally did not follow the custom of fasting during Ramadan or performing daily prayers. Moreover, the women in the community did not wear veils, nor did they occupy a different space than men in the religious house. It seemed as if the traditional spatial division based on gender was not present in the Alevi community. On the other hand, Sunni respondents generally declared following Ramadan and daily prayers, although they did not always do it in the orthodox way. In addition to this, all female Sunni respondents were veiled.

\section{Methodology}

The methodological framework of the research discussed here is driven by Situational Analysis - an inductive method drawn up by Adele Clarke (2005, 2009). The data was collected between December 2012 and January 2014, using the technique of semi-structured in-depth interviewing. 12 interviews with second- and thirdgeneration Norwegian Turks are discussed here. The interviews started from the "selfportrait without self" schema. Respondents were asked to name and write down things that made them who they are. The things were divided into five separate groups: (1) belongings that are important to the respondents; (2) spaces, places and landscapes they identify with; (3) people who made them who they are; (4) ideas, values, and emotions that describe them; and (5) activities in which they can express themselves. In the first part of the interview the elements written down by the respondents were discussed. Interlocutors were asked for explanations about why the thing, place, person, idea or activity was important to them and how it made them who they are. During this part, the respondents were also asked to briefly introduce themselves. The second part of the interview was more structured and was comprised of questions concerning the respondents' routine practices. The interview was designed in this way in order to avoid classifying practices and identifications as Turkish or Norwegian. However, in their narrations, such classification was often made by the respondents themselves. The interviews were anonymous and with the exception of one that was conducted in English, the rest were all held in Norwegian ${ }^{8}$. The latter was chosen as the language of the interviews so that the Turkish identification of the respondents would not be prioritized, as this could have influenced the findings. It seemed to be the most neutral choice, since the interviews were conducted in Norway, where minorities speak Norwegian in public. All but one interview was recorded and transcribed because a respondent did not give his/her consent to be recorded. The interviews were conducted in various locations, which included public places and ethnic clubs. I was never invited to a private house.

\footnotetext{
${ }^{7}$ The inspiration came from Douglas Harper's visual method of self-portrait without self (Harper 2012).

8 The respondent suggested conducting the interview in English, not because he/she was not fluent in Norwegian, but as an act of courtesy with the researcher, who was more fluent in English than in Norwegian.
} 
The sample was selected via snowball sampling. The whole process was difficult given that many immediately rejected to take part in the research and also because candidates that had accepted to participate and given their consent withdrew from the study. Eventually, 12 respondents that represented different genders, levels of education, sectors of employment and who were linked to different Turkish communities in Drammen were recruited. Their common feature was a rural origin and the former "guest worker" status of their ancestors.

\section{Heritage ANd Belonging. Boundary Making ANd Crossing}

The respondents built their narrations around several axes such as "Turkishness", Islam, work and social life. The most common one was the widely understood "Turkishness" that covered practices and values assumed to be common in Turkish society and among ethnic Turks. The second important axis was Islam and it primarily included typical religious traditions of Turkish Sunni Islam ${ }^{9}$. Narrations that revolved around work and social life were rare and came exclusively from young, unmarried respondents. Despite the fact that all of the respondents participate in each of the aforementioned areas - Turkish and religious communities, work (school) and social life - most of them chose to build their narrations around their Turkish heritage. This reveals their self-identification as Turks and their sense of belonging to their ancestors' places of origin in Turkey. On the other hand, the threads concerning participation in Norwegian society, either through professional work or by sharing particular values and practices that are common in Norwegian society, reflectthe other side of belonging: local belonging to Norway. The following section of this paper discusses how dual belonging to Norway and Turkey is organized and accomplished by the respondents and how the boundaries between us and them are being made and crossed.

\section{V.1. Dual Belonging}

The respondents were asked to name the places that have made them who they are and that are important to them. The great majority of answers included a combination of localities in Norway and Turkey. The city of Drammen, which is where respondents lived, was mentioned among the places in Norway, usually with special regard to the particular district in which the respondents grew up. Without a doubt, the local sense of belonging to the Norwegian city was shared among the respondents and, along with the mentioned districts, incorporated the true idea of home:

The most important landscape for me is [the District in Drammen] because this is where I grew up; all of my friends are from [there]. I feel at home there. If I for example drive from Oslo, I feel like I am in a foreign place. But when I start driving towards [The District in the City], I feel at home. When I am in [another city], I am

\footnotetext{
${ }^{9}$ Common Turkish Sunni Islam practices were also present in the narrations built around "Turkishness". However, those who built their narrations around the axis of Islam presented a lack of threads concerning secular values and practices common in Turkey. Since the religious axis was chosen exclusively by the respondents with Sunni backgrounds I mention here practices of Turkish Sunni Islam.
} 
bored. But when I drive towards [The District in the City], even though there is nothing to do here, I feel at home. So the most important area for me is [the District in the City]. Otherwise it doesn't matter to me where I am (Alevi Respondent 7).

Areas... I have mainly written Drammen since I was born and raised here. Drammen has formed me. I was born here, I raised here (...). I have also written [The District in the City]. This is where I live. (...) I belong to Drammen. (Alevi Respondent 12)

While all the respondents expressed a strong local attachment to Norway, the majority of them simultaneously reported an attachment to localities in Turkey. This was especially applicable to Norwegian Turks with a Sunni background, regardless of thegeneration they belonged to. At the beginning of the conversation, many of the interlocutors told me at that they were from Turkey, ignoring the fact that they were born and raised in Norway. They labelled the city of Konya as home, which is where most of the Norwegian Turks in Drammen have their roots ${ }^{10}$ :

I was born and raised in Norway but I am originally from Turkey, of course. I come from Konya (Sunni Respondent 8).

Local belonging to the places in Turkey refers to the phenomenon of autochthony understood as being "born from the soil" (Geschiere 2009, p.ix). One of the respondents (Sunni Respondent 9) expresses the idea of autochthony by explicitly referring to the Turkic peoples and Anatolian Culture as "the real roots" of Turks the respondents identify themselves with. These discourses of Anatolia as the cradle of Turkish culture and the brotherhood of Turkic peoples have also been present in Turkey. Rural Anatolian origin has been used in common Turkish discourse as a metaphor for being honourable and it was traditionally opposed to urban life, which was synonymous with losing one's innocence due to modernization and western influences. The discourse of the people of Anatolia as the real ancestors of Turks was also present in Ataturk's rhetoric and played a role in the nation-building processes in Turkey.

The autochthonic discourse of "real" belonging had another dimension in the narrations that involved blood ties with the soil:

Had they instructed me that I should [choose to] stay either in Turkey or in Norway, so I would have chosen Turkey. Because that's where my blood really originated. (Sunni Respondent 11)

Belonging to Turkey is often supported and legitimized by having a home in Turkey. Some respondents or their families own a house in Turkey, often in the local

\footnotetext{
${ }^{10}$ In further conversations, they often replaced Konya first with a smaller city in the province and eventually with the exact villages in the area from which their ancestors originated. The city of Konya was commonly used in the community of Norwegian Turks based on the assumption that the interlocutor did not know Turkish geography.
} 
areas of their ancestors' origin. These houses serve as holiday residences and the fact of owning them mirrors similar practices of many middle-class ethnic Norwegians who for other reasons - buy houses in the South, including Turkey. Norwegian Turks' yearly journey to Turkey has become a tradition that is facilitated by home ownership, imposing an additional element of meaning on these trips: that of "coming back home”.

Respondents of Alevi origin tended to express a quite strong sense of belonging primarily to Norway. There were a few persons who did not indicate having any attachment to Turkey and these were of Alevi origin. The rest of Alevi Norwegian Turks manifested a sense of belonging to Turkey. However, the place in Turkey they labelled as "home" was not the village of their ancestors in the Konya Province, but Izmir, which is one of the most modern cities in Turkey and also the place where their family members that remained in Turkey currently live:

I like Drammen very much. This is my city. (...) I feel at home here. But I have also written Turkey - Izmir. This is my second home. My mother and father are from Turkey, so I am part of that (Alevi Respondent 4).

Some of the Alevi respondents express non-identification with Konya, explicitly highlighting the striking difference between common habits in the province and those of the abovementioned Turkish city: "Everyone in Konya is very religious. (...) But in Izmir, it is like in Norway, people are modern. (...) Izmir suits me better than Konya” (Alevi Respondent 12).

The relationship between Sunni and Alevi Muslims in Turkey is marked by a negative heritage. A series of reasons, such as pogroms of Alevis that have taken place in the past ${ }^{11}$ and the little support that this community has received from the current Turkish government ${ }^{12}$ might influence their strong attachment to Norway, where the Alevi community is free to practice its liberal version of Islam. It could also explain the rejection of conservative and predominantly Sunni Konya in favour of other modern Turkish cities.

\footnotetext{
${ }^{11}$ Esra Özyürek(2009, p.237) mentions several pogroms of Alevis in Turkey: “(...) hundreds of Alevis were killed by Sunni Muslim and Turkish nationalist fanatics in Sivas (1978 and 1993), Kahramanmaras (1978), Çorum (1980), and Gazi in Istanbul in 1997“. (See also Shankland 2007, p.1)

${ }^{12}$ In Turkey there is a governmental department, the Directorate of Religious Affairs (DiyanetIsleriBaskanligi), which oversees matters of religion in the country. As Elisabeth Özdalga(2012, p.213) argues: "Its field of activity is more or less defined by four pillars of Islam - ritual prayer (namaz), fasting during Ramadan (oruç), pilgrimage (hac), and almsgiving (zekat) - as well as sacrifice (kurban). To this have been added education (Qur'an sources), seminars and conferences and various publishing activities." The directorate however ignores in its activity the Alevis - the biggest religious minority in Turkey. Özdalga (ibid.) continues: "The Diyanethas played a stabilizing role with respect to Sunni Islam, but in relation to the Alevi community it has failed to fulfil its mission as a secular - or neutral institution. Alevi grievances are concentrated on the lack of representation within the Diyanet, the total silence on Alevism in public school education, and the unwillingness to allow special houses of worship (cemevi) for Alevis.” (See also Shankland 2012, p.113)
} 
Belonging consists of much more than just a physical place. The aforementioned locations in Turkey and Norway that have become arenas of the respondents' belonging are strictly connected to the people and communities acting within them.

An important arena of social belonging of the respondents is family. All of them claimed that their family had played a significant role in their lives:

The Family means for me to support each other, to stand back each other when one need help. I have received a lot from my family (Sunni Respondent 11).

Some respondents indicated that they feel at home in Norway since their family is there. Family is not limited to their closest relatives. While talking about family, they actually referred to their extended family, which included more than 50 people in some cases. Most of the respondents also stated that a significant number of their family members were living in the area of Drammen. Family is an institution in which mutual support, including financial help, is common. Family is also an arena in which practices, traditions and values that constitute elements of Turkish heritage are recreated and renegotiated: "Culture is the tradition of my family, because I share something from them. Norwegian and Turkish traditions, both" (Sunni Respondent 3). Turkish Bayrams (religious celebrations) are followed with and within the family, and family meetings are pretexts to cook time-consuming Turkish dishes. Finally, family instils certain values, such as respecting and obeying older people. Family is an important reference point for all the respondents, who feel that family members have shaped their personalities. The processes that have been described reflect the significance of kinship in traditional Turkish society (Meeker 2002), as well as a collective, rather than individualistic orientation of an entity.

Besides family, other arenas of social belonging are formal and informal Turkish communities in Norway. A very strong sense of belonging to a formal Alevi community was observed among all the respondents that had an Alevi background. In the case of Sunni respondents, important Turkish communities, except for Turkish mosques, were rather informal or semi-formal ones: friend circles and semi-formal ethnic clubs where men originating from particular places in Turkey gathered. The groups and institutions that have been designed by Norwegian Turks and are run by them provide activities as diverse as Turkish dance, Turkish guitar classes, worship practices, Turkish cooking courses or activities such as playing cards and board games while drinking tea. All of these are either common practices of many people in Turkey or have a direct connection with Turkish cultural heritage, transforming the communities into arenas of heritage preservation, recreation and renegotiation.

Gender division is one of the most controversial elements of Turkish heritage. While many Norwegian Turks ${ }^{13}$ criticize it, this division is maintained within many

\footnotetext{
${ }^{13}$ See, for example, the discussion around Islamic seminars that took place at the Oslo and Akershus University College, and which was organized by one of the religious associations of Norwegian Turks. During the seminar, men were asked to sit separately from women. This opened a discussion and many
} 
formal and informal communities of Norwegian Turks. In ethnic clubs frequented by Sunni Norwegian Turks there is a traditional gender division and the presence of women is rather uncommon there. Conversely, Turkish cuisine courses are frequented almost exclusively by women. In addition to this, Sunni mosques provide separate spaces for men and women, contributing to the perpetuation of the gender division that has traditionally been common in Turkey, especially in rural areas, although it is rather unacceptable in Norway.

Participation in communities of Norwegian Turks in Drammen deepens the sense of autochthonic belonging to Turkey and strengthens the identification with a group. However, the main contribution of these communities is building the attachment to the local in Norway. Consequently, most of the respondents declared to have a sense of belonging both to the new homeland and their ancestors' homeland. This sense of belonging was created and enforced within the local Turkish community in Norway.

\section{V.2. Dual (non)belonging}

The quest for indigenity, which was expressed in the respondent's declaration of "being from Turkey", is based on the reflection of gradually common discourses of autochthony in Europe, as observed by Peter Geschiere (2009). Such discourses seek to approach identity as something that is deeply rooted and bounded to a "primary origin" and that has the effect of making immigrants and their offspring born in the new homeland foreign. The problem described by Geschiere exists in Norway as well, where Norwegian-born members of immigrant minorities might still be asked about where they really come from. The quest for autochthony forces minorities to relate the idea of "real home" to the remote localities that they or their ancestors left many years ago. Such strategies provide an alternative story to help build one's self-definition and limit the risk of feeling like "being from nowhere". In some cases - such "remote" belonging is shared with enthusiasm. In others, however, it may lead to a crisis of belonging in which members of immigrant minorities are stuck in-between localities, unable to be fully accepted in any of them. The problem of this dual "non-belonging" is well described in the statements of respondent two, who arrived in Norway when she was ten years old. In the first part of her statement, she refers to her autochthonic belonging to Turkey. In the second part, she expresses her private opinion regarding where she feels at home:

Turkey is my homeland. When I arrive there, with no doubt I am at home. But, when I arrive in Norway, I am of course foreign (...). When I am in Oslo, I am foreign, but not in Turkey. Nevertheless, I feel at home here [in Norway] because here I have my life, my friends, my relatives, my family is here. (...) I couldn't think about moving back to Turkey. I have more here [in Norway] than there (Sunni respondent 2).

secular Norwegian Turks took part of it by criticizing the organizers and blaming them for giving a false idea of the Turkish community in Norway (for details see Torset 2014: text in Norwegian) 
Later in the conversation, respondent two admits to have been treated as a foreigner both in Turkey and Norway:

I don't feel at home in Turkey either because (...) they say there that you are from abroad in a way. (...) [In Norway, on the other hand,] even if one forgets that one is foreign here, the others will never forget it (Sunni respondent 2).

As the statements of respondent 2 show, this sense of non-belonging is created and enforced by others - both Turks and Norwegians- while the respondent herself has a quite clear idea of where she feels at home. Ahmet İçduygu (2009, p.26) argues that Turks who emigrated abroad were given the nickname of "Almanyalı" by the nonmigrant population in Turkey. The direct translation of this term would be "Turks from Germany”, which is a concept based on their modernized behaviour which is different to that of those who stayed in the villages.

Another Sunni Respondent who declared to have a strong attachment to Turkey also admitted further on in the narration that she was excluded from Turkish society and seen there as a foreigner:

I feel at home more in Norway than in Turkey. I feel foreign once I am down there (in Turkey). If you (...) didn't know that I was from Turkey, you wouldn't guess I am foreign [in Norway] because you couldn't hear it from my language. But when I am in Turkey, then at once: “Are you coming from abroad?” (Sunni Respondent 8).

As a statement of respondent eight shows, the use of Turkish language becomes an excluding factor in their ancestors' homeland, even though it actually constitutes an important element of Norwegian Turk heritage. Turkish is widely spoken in the Turkish community in Norway; all the respondents use Turkish at home and consider it to be their mother tongue. Language draws a clear boundary of Turkish ethnicity and strengthens the sense of belonging to the Turkish community in Norway. Nevertheless, language used by the Turks abroad, including the second and subsequent generations, has not undergone the same changes as Turkish used in Turkey, which is why it might sound a bit old-fashioned or foreign in Turkey. Thus, the use of Turkish in Turkey may become a cause of exclusion, for instance, in cases such as that of respondent eight, who has a different accent. On the other hand, fluency in Norwegian helps cross the group's boundary and move closer to Norwegian society. This explains why many of the respondents give importance to the fact that their children learn Norwegian thoroughly, as they themselves were able to adapt to the Norwegian society by being fluent in this language. This is a starting point for a discussion about heritage of Norwegian Turks and it also raises the question of whether Norwegian language will become part of Norwegian-Turkish heritage in the future or not.

As I have exemplified, the necessity of constant negotiations of belonging blurs the respondents' self-definition, making them seem apparently stuck in in-betweenness: 
I feel that I am 50\50. I am not fully Turk. (...) I cannot say I am fully Turk nor can I say that I am fully Norwegian (Alevi Respondent 12).

The respondents`solution to such a vague self-definition is developing a sense of belonging to the local in Norway. They do so by becoming part of formal and informal networks of Norwegian Turks, as well as by establishing connections with local places in Norway. This should not, however, be regarded as integration into the Turkish community, but rather integration into Norwegian society under the Turkish umbrella identity. By belonging to social networks of Norwegian Turks, which are strengthened and maintained thanks to a shared heritage, the respondents feel comfortable in the local environment in Norway. Consequently, it gives them the foundation to renegotiate traditional practices and values, bringing them closer to those common among ethnic Norwegians without losing the sense of autochthonic attachment to Turkey. Even if from the national-ethnic perspective of Turkey and Norway the socalled in-betweenness is a fact, the respondents are not between the localities. They develop an unique identification with Norway under the umbrella of "Turkishness", and implement practices and values that bear Turkish, Norwegian and global influences.

\section{V.3. Heritage: boundary making and crossing.}

As I mentioned before, while searching for their autochthony and going through different crises of belonging, the respondent send up looking for their own roots in Turkey, while legitimizing their presence in Norway. Since belonging, especially of immigrants, is constantly questioned in Europe, both in everyday conversations and in public and political discourse, it has become processual and constantly negotiated. This problem is especially acute for second and further generations, born in new homelands, who are not fully accepted by members of a society they are growing up in nor have they had the chance to belong to another place "by birth". Those people are forced to create their reflexive self-identity (Giddens 1991) to reach compact narrations of their lives. To do so, they renegotiate and adjust Turkish history, traditions and practices inherited from their ancestors, to the living environment in Norway. In this section, I discuss practices that have become intersections of Turkish and Norwegian influences and that will eventually contribute to the cultural integration of Norwegian Turks into the society of their new homeland.

One of the commonalities that exist between Turkish heritage and the Norwegian system of values is the narration of the Ottoman Empire. Norwegian egalitarian values, with a focus on equality between people of any religious or ethnic background, are shared by most of the respondents. Some of them explicitly admit that this is what they like about Norway. However, others who share those values do not connect them to Norwegian society, but to the heritage of the Ottoman Empire instead:

I'd like to pass down the respect. This is what I identify with. In the Ottoman Empire, there were many different ethnicities and people but nobody forced them to follow Islam. Everyone could've one's own culture and religion. There 
was no racism but there was respect. If it hadn't been for that respect, the Empire would've had collapsed. It wouldn't have lasted that many years. Muslims would live with Christians and there was no problems (Sunni Respondent 9).

The respondent gives an example of Istanbul as a historically heterogeneous city. Indeed, the district that is known today as Beyoglu, in Istanbul, was traditionally inhabited by many ethnic and religious minorities. However, while ethno-linguistic indifferences were common in the Ottoman administration, İçduygu and Soner (2006, pp.448-449) argue that Ottoman policies, together with its millet system, which classified inhabitants according to their religious origin, actually failed to provide equal treatment of disparate people. Modern Turkey, upon the foundation of the Republic in the 1920s, has actually followed the millet schema, incorporating Islam in the definition of a Turk and assuming the homogeneity of Muslims in the country (see İçduygu, Çolak \& Soyarik 1999; İçduygu \& Soner 2006, p.452). Those processes were responsible for the events that occurred during the $20^{\text {th }}$ century in Turkey, which denied the idea of ethnic and religious equality. The broadly discussed issue of the Armenian genocide (Akçam 2012; Suny 2015) can also be included here. Moreover, the current conflict between Kurds and Turks and the relatively limited governmental support of Alevism indicate that modern Turkey does not prioritize ethnic or religious equality in society. In contrast, the idea of equality of all people is a principle that constitutes Norwegian heritage. The strategy of respondent nine, aimed at legitimizing the values inscribed in Norwegian heritage with the use of the Turkish past, help him create a compact narration of the self. He links his modern self to Turkish cultural heritage to reach the sense of direction and progress (Taylor 1989). As a consequence, the respondent manages to reconcile his strong identification with Turkey with the egalitarian values spread in Norway that he eagerly shares.

The concept of respect is one of the most important values shared by the respondents. It can be understood twofold: respect as equality between people of different backgrounds, as described by respondent nine, and respect as offering help to other people and acting with a polite demeanour towards elders as well as being obedient. The latter understanding of respect is widespread in Turkey:

[My mother has taught me] to show respect to older than me. For example, Norwegians can say "one's name come here”. But have I done this in Turkey, would it be considered as rude. One should always say "brother". (...) Abi or $A b l a^{14}$. We have a lot of respect to those who are older than we are and we are helpful to those who are younger than we are. (Sunni Respondent 11)

Such a hierarchy between people of different ages is uncommon in the flat structure of Norwegian society and many of the respondents build the boundary of Turkish ethnicity upon such an understanding of the concept of respect. They usually combine it with the idea of helping others, which is broadly understood and assumed to

\footnotetext{
${ }^{14}$ In Turkish, Abi means «older brother»; Abla means «older sister».
} 
be common among Turks but foreign in the individualistic Norwegian society. On the other hand, respect, interpreted as equality, mirrors widespread values in Norwegian society and maintaining it helps cross boundaries between practices assumed as Turkish or Norwegian. Therefore, the use of the concept of respect strengthens the respondents' belonging to the group of ethnic Turks; at the same time, with the help of the Turkish past, it legitimizes the core values of Norwegian society, thereby facilitating integration into the society of the new homeland without losing the autochthonic sense of belonging to what is considered to be Turkish.

Traditions are other arenas in which Turkish heritage engages with practices common in Norway and vice versa. The most widely celebrated Turkish traditions are religious Bayrams that are, however, linked to the general "Turkish" rather than "Islamic" culture. Celebrating traditions deepens the sense of belonging to Turkey and strengthens the borders of Turkish ethnicity among Norwegian Turks. The respondents try to recreate a form of celebration from Turkey that involves eating Turkish food and visiting friends. However, in some cases, the way in which the festival is celebrated has been adjusted to the Norwegian reality. Some of the respondents include Christmas traditions such as an advent calendar in the celebration of Ramadan. Children are given small presents during the whole period of Ramadan, following the Christian tradition during the advent.

They receive [the small gifts] during Ramadan. Before Ramadan and Ramadan Bayram they got the gifts. (...) Even if we don't celebrate Christmas, now we do. (Sunni Respondent 2)

Christmas traditions that are widely celebrated in Norway have been included in Islamic religious fests even though the respondents generally do not celebrate Christmas. Transforming Turkish traditions and adding elements of Christian heritage actually introduces a new practice that is linked more to the community of Norwegian Turks than to Turkey. The boundary of Turkish ethnicity is maintained, but the practices of the members of the group actually cross that boundary. This practice might be regarded as another potential intersection of Turkish and Norwegian heritage that may become a feature of a heritage of Norwegian Turks.

Another area where cultural practices of Norwegian Turks intertwine with Norwegian heritage is the celebration on May $17^{\text {th }}$ of Norway's Constitution Day. This day is widely celebrated both by ethnic Norwegians and minorities. Some Turkish communities, such as the Alevi association, organize activities for the event and Turkish food is included in the celebrations. Individual Norwegian Turks celebrate by participating in the city's parade, while wearing nice clothes and waving the Norwegian flag.

I always participate in May $17^{\text {th, }}$ s celebrations. I always take part in the May $17^{\text {th }}$ parade. I have always been in. I go around with a Norwegian flag and I say "hip hip hurrah!” I am in the city. I have always wanted to buy a bunad. (Sunni Respondent 8). 
Some of the female respondents indicated they would like to own a bunad, which is a traditional Norwegian folk costume that is widely used by women during the celebrations. This wish is however limited by the financial capacities of the respondents: they consider abunad to be very expensive. Nevertheless, active participation in the celebrations of May $17^{\text {th }}$ - one of the most important elements of Norwegian heritage - and the will to do it in a traditional folk dress, undoubtedly strengthens the sense of belonging to Norway. There are several bunad designs and each of them is related to a particular place in the county. The question that arises here is whether the interest in a bunad might express the respondent's quest for autochthony in Norway or not. Considering that the respondents who articulate the desire to have a bunad were young females, one may assume that they were rather influenced by the widely spread fashion among ethnic Norwegian female youths of wearing the costume.

The May $17^{\text {th }}$ parade may be analysed as communitas, understood by Viktor Turner (1995) as an alternative institution of community that is free from everyday structures and hierarchies. In communitas, all the people are equal and included. For that reason, it becomes easier to explicitly express identification with the Norwegian flag and heritage, as well as to try to look like ethnic Norwegians, in the context of the parade than in other circumstances. Participation in the May $17^{\text {th }}$ parade gives the respondents the chance to publicly express their belonging to Norway. Even if the identification with communitas is temporary, the fact that they participate every year, dress up and wave the Norwegian flag, indicates that Norwegian Turks have permanently joined and found their place in this Norwegian heritage.

The permanent place of the Turkish minority in May $17^{\text {th }}$ celebrations in Norway involves boundary making and crossing. On the one hand, the group's boundary is maintained. On the other, by sharing "Norwegian” practices, symbols and even clothing styles, the borderline of Norwegian heritage is crossed. In the context of the May $17^{\text {th }}$ celebration, I observed the manifestation of belonging to the multicultural Norwegian society, while preserving the "Turkish" identification. Such belonging, however, was not the case for a few respondents, who rather declared themselves as external observers of this festivity:

I know this is not my tradition, this is not my celebration. I was born and raised in Norway so I need to show respect [and celebrate May $17^{\text {th }}$ ] of course, but this is not my celebration, I don’t belong with it, I am an observer (Sunni Respondent 11).

Nevertheless, despite the meaning given to Norway's national day by individuals, May $17^{\text {th }}$ has become a tradition celebrated by Norwegian Turks; in all of the narrations it was mentioned in line with Ramadan and Kurban Bayram - religious holidays in Turkey. I would not risk saying that May $17^{\text {th }}$ has become a heritage of Norwegian Turks since it is clearly Norwegian heritage. Norwegian Turks, however, have become part of this Norwegian heritage, celebrating it together with ethnic Norwegians, under the umbrella of Turkishness and with the inclusion of Turkish practices such as sharing Turkish food and paying visits to family or friends. 


\section{CONCLUSIONS}

Heritage plays an important role in setting the boundary of Turkish ethnicity. It strengthens the respondents' autochthonic sense of belonging to Turkey and it serves as a foundation for their reflexive narrations of the self. Since the "natural" belonging to Norway of second and third-generation Norwegian Turks is questioned, such a shift towards "Turkishness" is crucial for maintaining the compact self-definition and avoid the feeling of "being from nowhere". On the other hand, being born outside Turkey and having a foreign accent when speaking in Turkish, casts doubt upon the respondents' belonging to Turkey. Moreover, cultural practices and values that constitute Turkish heritage are elements of constant renegotiations according to the circumstances and requirements of the society of the new homeland. The sources of those practices date back to the 1960s and 1970s and refer to the rural origins of the respondents' ancestors. The changes that these practices have undergone over time have been different to the changes that similar practices in Turkey have suffered, leading to different results in their current meanings and interpretations. Consequently, second and third-generation Norwegian Turks have formed new unique cultural patterns that involve habits brought by the first generation from Turkey and transformed by Norwegian society's influences. Since those new values and practices are not specific or common neither to today's Turkish society nor Norwegian society, the respondents have developed a strong sense of belonging to the "third space" ${ }^{15}$ : an informal community of Norwegian Turks in which these diverse practices and systems of values are understood and shared. The third space is physically located in Norway, and this is where the majority of the respondents "feel at home". Cultural integration into Norwegian society therefore takes places under the umbrella of Turkish ethnicity. It makes its way by renegotiating traditional Turkish heritage in everyday practices of individuals and legitimization of Norwegian systems of values and traditions through the use of Turkish history. This makes cultural integration of Norwegian Turks into the society of the new homeland an invisible and slow process that is nevertheless present and moving forward. New practices have the potential to become a unique heritage of Norwegian Turks, reflecting the process of cultural integration into Norwegian society within the framework of Turkish ethnicity.

The narrations about belonging and participation in Turkish and Norwegian heritage expressed by Alevi and Sunni respondents were rather consistent, although some nuances between them have been observed. Firstly, Alevi respondents seemed to have stronger ties with Norway than those that have a Sunni background. Their attitudes towards participating in the celebration of May $17^{\text {th }}$ were generally more enthusiastic and more often they referred to themselves as members of Norwegian society. Another

\footnotetext{
${ }^{15}$ See the discussion on the third cultural space comprising cultural activities linked to ethnicity (Eduardo J. Ruiz Vieytez, the same volume). Practices, traditions and systems of values described throughout this paper definitely constitute "the third cultural space" in Vievtz's understanding and, in line with religion and language, are present in daily practices of my respondents. However, "the third space” that I specify here has a slightly broader meaning, referring to collective identification with the vague community of Norwegian Turks, which is defined by language, religion and so-called cultural practices of people identifying themselves with Turks but living in Norway.
} 
difference that was observed had to do with the role of a situation currently taking place Turkey. While for Sunni Turks the current political situation of Turkey did not play a direct role in the projection of their belonging, Alevi respondents mentioned in their narrations discrimination of Alevis in Turkey, which constituted an important reference for their self-definition. Consequently, to Alevi respondents, the sense of belonging to Turkey was built upon the heritage of Alevism and Alevi`s unprivileged position in Turkey, so it could be said that this belonging was based on being part of the Alevi community. Sunni Turks` identification with Turkey, in turn, was expressed more directly and Sunni respondents tended to see themselves as members of a homogeneous nation of Turks.

\section{REFERENCES:}

ADRIAENS, F. (2014). “'Diaspora girls doing identities': Creating ideal television programmes and narratives of the self”. European Journal of Cultural Studies, 17(2), pp. 101-117. https://doi.org/10.1177/1367549413508096

AHMED, S. (1999). "Home and away: Narratives of migration and estrangement". International Journal of Cultural Studies, 2(3), pp. 329-347. https://doi.org/10.1177/136787799900200303

AKÇAM, T. (2012). The Young Turks' crime against humanity: The Armenian genocide and ethnic cleansing in the Ottoman Empire, Princeton University Press, Princeton.

AKKERMAN, T. \& Hagelund, A. (2007). “"Women and children first!” Anti-immigration parties and gender in Norway and the Netherlands', Patterns of Prejudice, 41(2), pp. 197-214, https://doi.org/10.1080/00313220701265569

ALGHASI, S., ERIKSEN, T. H. \&GHORASHI, H.(2009).Paradoxes of cultural recognition: Perspectives from northern Europe, Ashgate Publishing Ltd, Farnham.

ANDERSSON, M. (2012). "The debate about multicultural Norway before and after 22 July 2011”. Identities, 19(4), pp. 418-427.

https://doi.org/10.1080/1070289X.2012.684442

ANTHIAS, F. (2016). "Interconnecting boundaries of identity and belonging and hierarchymaking within transnational mobility studies: Framing inequalities”. Current Sociology,64(2),pp. 172-190.

https://doi.org/10.1177/0011392115614780

BANGSTAD, S. (2011). "The morality police are coming! Muslims in Norway's media discourses (Respond to this article at http://www.therai.org.uk/at/debate)". Anthropology Today, 27(5), pp. 3-7. https://doi.org/10.1111/j.1467-8322.2011.00825.x

BARTH, F. (1969). Ethnic groups and boundaries: The social organization of culture, Universitetsforlaget, Oslo. 
BARTH, F. (1994). 'Enduring and emerging issues in the analysis of ethnicity', in $\mathrm{H}$. VERMEULEN \& C. GOVERS (eds), The anthropology of ethnicity: Beyond 'ethnic groups and boundaries', Het Spinhuis, Amsterdam,pp. 11-32.

BAUMANN, G. (1999). The multicultural riddle: Rethinking national, ethnic, and religious identities, Routledge, New York.

BLOM, S. (1997). 'Bokonsentrasjon blant innvandrere i Oslo', in BROX,O.(ed), Tett eller Spredt? Om innvandrernes bosetninger i Norge,Tano Aschehoug, Norway,pp. 44-62

BLOMMAERT, J., COLLINS, J., \& SLEMBROUCK, S. (2005). "Polycentricity and interactional regimes in 'global neighborhoods'”. Ethnography, 6(2), pp. 205-235. https://doi.org/10.1177/1466138105057557

BOLT, G., \& VAN KEMPEN, R. (2002). "Moving Up or Moving Down? Housing Careers of Turks and Moroccans in Utrecht, the Netherlands”. Housing Studies, 17(3), pp. 401422. https://doi.org/10.1080/02673030220134926

BROCHMANN, G. \& KJELDSTADLI, K. (2008).A history of immigration: The case of Norway 900-2000, Universitetsforlaget, Oslo.

ÇAĞLAR, A. (2001). “Constraining metaphors and the transnationalisation of spaces in Berlin”. Journal of Ethnic and Migration Studies, 27(4), pp. 601-613. https://doi.org/10.1080/13691830120090403

ÇAĞLAR, A. (2004). "Mediascapes, Advertisement Industries and Cosmopolitan Transformations: German Turks in Germany”. New German Critique (92), pp. 39-61.

CLARKE, A. E. (2005).Situational analysis: Grounded theory after the postmodern turn, Sage Publications, California. https://doi.org/10.4135/9781412985833

CLARKE, A. E. (2009). "From grounded theory to situational analysis: What's new? Why? How?”, in MORSE, J. M. STERN, P. N.. CORBIN, J. BOWERS, B. CHARMAZ, K.\& CLARKE A. E. (eds), Developing grounded theory: The second generation, Developing qualitative inquiry, Left Coast Press, California.pp. 194-221

COHEN, A. P. (1994). "Boundaries of consciousness, consciousness of boundaries: Critical questions for anthropology”, in VERMEULEN H. \& GOVERS C. (eds), The anthropology of ethnicity: Beyond 'ethnic groups and boundaries', Studies on migration \& ethnicity, Het Spinhuis, Amsterdam,pp. 59-80.

DE VALK, H. A. G., \& LIEFBROER, A. C. (2007)."Parental Influence On Union Formation Preferences Among Turkish, Moroccan, and Dutch Adolescents in the Netherlands”. Journal of Cross-Cultural Psychology, 38(4), pp. 487-505. https://doi.org/10.1177/0022022107302316

DRAMMEN KOMMUNE, n.d. (2015) Fjell - en drabantby i Drammen, accessed January 25, 2015, from https://www.drammen.kommune.no/Documents/Politikk og lokaldemokrati/Presentasjoner/4 Fjell 2020 - Områdeutvikling.pdf. 
DRESSLER, M.(2008). "Religio-secular metamorphoses: The re-making of Turkish Alevism”, Journal of the American Academy of Religion, 76, pp. 280-311. https://doi.org/10.1093/jaarel/lfn033

GALIP, O. B. (2015).Imagining Kurdistan. Identity, Culture and Society, I. B. Tauris, London and New York.

GESCHIERE, P. (2009).The Perils of Belonging: Autochthony, Citizenship, and Exclusion in Europe and Africa, The University of Chicago Press. Chicago and London. https://doi.org/10.7208/chicago/9780226289663.001.0001

GIDDENS, A. (1991)Modernity and self-identity: self and society in the late modern age, Polity Press, Cambridge.

GRAHAM, B. (2002) “Heritage as knowledge: Capital or culture?”, Urban Studies, 39(5-6), pp. 1003-1017. https://doi.org/10.1080/00420980220128426

GÜNEY, S., KABAŞ, B., \& PEKMAN, C. (2016)."The Existential Struggle of SecondGeneration Turkish Immigrants in Kreuzberg: Answering Spatiotemporal Change”. Space and Culture, published online before print (May 8, 2016).

GUPTA, A., \& FERGUSON, J. (1992). "Beyond "Culture": Space, Identity, and the Politics of Difference”. Cultural Anthropology, 7(1), pp. 6-23.

https://doi.org/10.1525/can.1992.7.1.02a00020

HAGELUND, A. (2002). "Problematizing culture: Discourses on integration in Norway", Journal of International Migration and Integration / Revue de l'integration et de la migration internationale, 3(3), pp. 401-415.

https://doi.org/10.1007/s12134-002-1022-7

HAGELUND, A. (2003). The importance of being decent: Political discourse on immigration in Norway, 1970-2002, Unipax, Oslo.

HARPER, D. (2012). Visual Sociology, Taylor \& Francis, New York.

HØYDAHL, E. (2014). Innvandrere og norskfødte med innvandrerforeldre, SSB, Oslo.

İÇDUYGU, A. \& SONER, B. A. (2006). "Turkish minority rights regime: Between difference and equality”, Middle Eastern Studies, 42, pp. 447-468. https://doi.org/10.1080/00263200500521370

IÇDUYGU, A. \& TEKELIOGLU, O. (1995). "Turks in the Nordic countries: An overview”, in GÖKALP, A. KASTORYANO, R.\& DE TAPIAS. (eds), Turcs d'Europe..., et d'ailleurs, l’ERISM, Paris, pp. 205-214.

IÇDUYGU, A. (2009). "UNDP report: International migration and human development in Turkey”, Human Development Reports, no. 52.

İÇDYGU, A., ÇOLAK, Y. \& SOYARIK, N.(1999). "What is the matter with citizenship? A Turkish debate”, Middle Eastern Studies, 35(4), pp. 187-208. https://doi.org/10.1080/00263209908701291 
IÇDUYGU, A., TOKTAS, Ş. \& SONER, B. A. (2008). “The politics of population in a nationbuilding process: emigration of non-Muslims from Turkey”, Ethnic and Racial Studies, 31, pp. 358-389. https://doi.org/10.1080/01419870701491937

KAYA, A. (2001). Sicher in Kreuzberg: constructing Diasporas: Turkish-hip-hip youth in Berlin, Transcript, Bielefeld. https://doi.org/10.14361/9783839400715

KAYA, A. (2002). “Aesthetics of diaspora: Contemporary minstrels in Turkish Berlin”, Journal of Ethnic and Migration Studies, 28(1), pp. 43-62. https://doi.org/10.1080/13691830120103921

KAYA, A. (2007). “German-Turkish Transnational Space: A Separate Space of Their Own”, German Studies Review, 30(3), pp. 483-502.

LÄHDESMÄKI, T., SARESMA, T., HILTUNEN, K., JÄNTTI, S., SÄÄSKILAHTI, N., VALLIUS, A., \& AHVENJÄRVI, K. (2016). "Fluidity and flexibility of "belonging”, Acta Sociologica, 59(3), pp. 233-247. https://doi.org/10.1177/0001699316633099

MACDONALD, S. (2013). Memorylands: Heritage and identity in Europe today, Taylor \& Francis, London.

MCDOWALL, D. (2007). A modern history of the Kurds 3rd edn., I.B Tauris \& Co Ltd, London.

MEEKER, M. E. (2002). A nation of empire: The Ottoman legacy of Turkish modernity, University of California Press. https://doi.org/10.1525/california/9780520225268.001.0001

MELD. St. (2012). En helhetlig integreringspolitikk: Mangfold og fellesskap.

NÆSS, R. (1985). Innvandrere på norske arbeidsplasser. En studie av Tyrkiske og pakistanske innvandreres situasjon på et utvalg arbeidsplasser, Arbeidspsykologisk Institutt, Oslo.

NISTOV, I. (2001). Referential choice in L2 narratives: A study of Turkish adolescent immigrants learning Norwegian. Doctoral dissertation, Department of Linguistics, University of Oslo.

ÖZDALGA, E. (2012). 'Secularism', in HEPER M. \& SAYARI S. (eds), The Routledge handbook of modern Turkey, Routledge, London.

ÖZYÜREK, E. (2009) “"The light of the Alevi fire was lit in Germany and then spread to Turkey”: A transnational debate on the boundaries of Islam', Turkish Studies, 10, pp. 233-253. https://doi.org/10.1080/14683840902864028

PÉCOUD, A. (2004). "Entrepreneurship and identity: cosmopolitanism and cultural competencies among German-Turkish businesspeople in Berlin”,Journal of Ethnic and Migration Studies, 30(1), pp. 3-20.

https://doi.org/10.1080/1369183032000170141 
PETTERSON, M. (2009). 'The impact and the quest for a cultural heritage', in AKMAN, H.\& STOKENS, O.(eds), The cultural heritage of the Kurds, BRIC, Center for Development Studies, University of Bergen.

PETZEN, J. (2004). “Home or Homelike?: Turkish Queers Manage Space in Berlin”, Space and Culture, 7(1), pp. 20-32

https://doi.org/10.1177/1206331203256851

PHALET, K., \& SWYNGEDOUW, M. (2002). "National identities and representations of citizenship: A comparison of Turks, Moroccans and working-class Belgians in Brussels”, Ethnicities, 2(1), pp. 5-30. https://doi.org/10.1177/1469682002002001520

RENIERS, G. (2001). “The post-migration survival of traditional marriage patterns: Consanguineous marriage among Turkish and Moroccan migrants in Belgium”, Journal of Comparative Family Studies, 32, pp. 21-44.

ROGSTAD, J. (2009). “Towards a Success Story? Turkish Immigrant Organizations in Norway”, Turkish Studies, 10(2), pp. 277-294. https://doi.org/10.1080/14683840902864044

SANDRUP, T. (2013). Farfars hus: norsktyrkiske familier : innvandrede utvandrere, PhD Thesis, Universitet i Oslo, Unipub.

SHANKLAND, D. (2007). The Alevis in Turkey: The emergence of a secular Islamic tradition, Routledge Taylor \& Francis, London.

SHANKLAND, D. (2012). 'Islam', in HEPER M. \& SAYARI S. (eds), The Routledge handbook of modern Turkey, Routledge, London.

SOYSAL, L. (2001). "Diversity of Experience, Experience of Diversity: Turkish Migrant Youth Culture in Berlin”, Cultural Dynamics, 13(1), pp. 5-28. https://doi.org/10.1177/092137400101300101

SPIERINGS, B., VAN MELIK, R., \& VAN AALST, I. (2016)."Parallel Lives on the Plaza: Young Dutch Women of Turkish and Moroccan Descent and Their Feelings of Comfort and Control on Rotterdam's Schouwburgplein”, Space and Culture, 19(2), pp. 150-163. https://doi.org/10.1177/1206331215620994

SSB STATISTICS NORWAY. (2015). Immigrants and Norwegian-born to immigrant parents, 1 January 2015, accessed from http://www.ssb.no/en/befolkning/statistikker/innvbef/aar/2015-03-04.

STEINKELLNER, A. \& RUSTAD HOLSETER, A. M. (2013). Befolkningens utdanningsnivå, etter spørreundersøkelsen om utdanning fullført i utlandet, Oslo.

STJERNØ COMMITTEE (2008). Mangfold og mestring - Flerspråklige barn, unge og voksne i oppleringssystemet [Diversity and Mastery - Multilingual Children, Young People and Adults in the Education and Training System] NOU 2010:7. 
SUNY, R. G. (2015) 'They can live in the desert but nowhere else': A history of the Armenian genocide., Princeton University Press, Princeton. https://doi.org/10.1515/9781400865581

TAYLOR, C. (1989) Sources of the self: the making of the modern identity, Cambridge University Press, Cambridge.

TORSET, N. S. (2014). «Kvinner og menn måtte sitte adskilt på islam-seminar på Høgskolen i Oslo og Akershus», Aftenposten.

TÜRKER, E. (2000). Turkish-Norwegian codeswitching: Evidence from intermediate and second generation Turkish immigrants in Norway, PhD thesis, Faculty of Arts, Universitet i Oslo.

TURNER, V. W. (1995). The ritual process: structure and anti-structure, Aldine de Gruyter, New York.

VAN ECK, C. (2002). Purified by Blood: Honour Killings amongst Turks in the Netherlands, Amsterdam University Press, Amsterdam.

VESTEL, V. (2009). "Limits of Hybridity Versus Limits of Tradition?: A Semiotics of Cultural Reproduction, Creativity, and Ambivalence among Multicultural Youth in Rudenga, East Side Oslo”, Ethos, 37(4), pp. 466-488. https://doi.org/10.1111/j.15481352.2009.01069.x

YUVAL-DAVIS, N. (2006). "Belonging and the politics of belonging”, Patterns of Prejudice, 40, pp. 197-214. https://doi.org/10.1080/00313220600769331

YUVAL-DAVIS, N. (2011). Power, intersectionality and the politics of belonging, Aalborg University, working paper series no. 75.

ZIRH, B. C. (2012). "Following the dead beyond the 'nation': a map for transnational Alevi funerary routes from Europe to Turkey”, Ethnic and Racial Studies, 35(10), pp. 17581774. https://doi.org/10.1080/01419870.2012.659274 